原著

\title{
一農村地区における成人健診受診者の 歯肉増殖有病についての検討
}

一一特に高血圧症・心疾患にかかわる服薬と雪肉増殖の関係——

\author{
Prevalence of Gingival Hyperplasia in Adults Receiving \\ a Health Examination in a Rural Area, in Reference \\ to Medications for Hypertension and Cardiopathy
}

\author{
岩 倉 政 城 ${ }^{* *}$ 橴谷 芳 郎**安 野 陽 子** \\ 島田義弘 ${ }^{* * *}$ \\ Masaki IWAKURA**, Yoshiro SHIBUYA ${ }^{* *}$, Yoko YASUNO** \\ and Yoshihiro SHIMADA***
}

Received March 25, 1991 ; accepted May 24, 1991

\begin{abstract}
Visual inspection for gingival hyperplasia was done and a drug questionnaire was given to 747 adults (male 317, female 430, 54.39 years old in mean) who received a health examination in a rural area of Miyagi prefecture. Characteristic gingival hyperplasia with four features (unevenness, multiplicity, demarcation and imposibility of explanation by local factors only) which we had detected at nifedipine medicated subjects was also examined. Persons receiving medication for hypertension or cardiopathy were classified as the medicated group and others as the nonmedicated group. Prevalence of gingival hyperplasia was $15.27 \%$ and $10.42 \%$, respectively, but no statistical difference was found between the two groups (Table 3). The characteristic gingival hyperplasia was detected in twelve persons $(5.91 \%)$ of 203 in the medicated group and in one person $(0.19 \%)$ of 518 in the nonmedicated group, with high statistical difference $(\mathrm{p}<0.01)$.

This prevalence $(5.91 \%)$ is about half the value which we reported for characteristic gingival hyperplasia $(10.9 \%)$ in private hospital patients receiving nifedipine for hypertension or cardiopathy. Considering the fact that about half of the hypertension or cardiopathy patients in this hospital were treated with nifedipine $(53.8 \%$ ), prevalence value of the present study $(5.91 \%)$ is not contradictory.
\end{abstract}

索引用語 : 歯肉增殖, 薬物副作用, ニフェジピン

Koy words: Gingival hyperplasia, Side effects of Drugs, Nifedipine

* 本論文の要旨は第39回日本口腔衛生学会総会において発表した。

** 東北大学齒学部予防歯科学講座

** Department of Preventive Dentistry, Tohoku University School of Dentistry

*** 鶴見大学女子短期大学部

*** Women's Junior College, Tsurumi University 


\section{緒言}

我々は $\mathrm{Ca}^{2+}$ 拮抗剤の一っであるニフェジピンによっ て起こった著明な歯肉増殖を予防歯科外来で観察し, 本 剤の投薬を中止することでその増殖が消退することを観

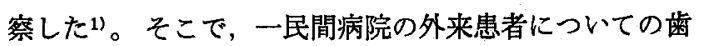
肉增殖と服薬調查からニフェジピン服用者の $10.9 \%$ に特 徵的な歯肉増殖が起こることを帛，またそれは，凹凸を 伴う, 多発性, 境界が明瞭, 增殖が局所要因だけでは説 明できない，の 4 項目で特徴づけられることを報告し

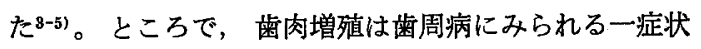
でもあり，また著明な歯肉増殖をもたらすものとして薬 物由来ではフェニトイン歯肉増殖などが挙げられ，この 他に娃娠, 思春期のホルモンバランスの変調によっても たらされるもの，歯肉繊維腫症などが知られている6)。 従って, ニフェジピンなど特定の薬物によって誘発され る歯肉増殖症の有病調查を行うにあたって, それ以外の 因子でおこる歯肉増殖の出現頻度の baseline を知るこ とは有用である。我々は，一地区における成人健診受診 者について歯肉増殖の有病率を，また，我々が報告した ニフェジピンに特徵的とみなした 4 項目を满足させる歯 肉增殖の有病状況を調查した。これらの結果と, 併せて 行った受診者の薬物服用についての質問紙調查成績との 間に興味ある知見を得たので報告する。

\section{対象ならびに調査方法}

宮城県北部の一農村地区における成人健診受診者のう ち，歯肉増殖の評価が可能な歯を 2 歯以上持つ者 754 名 を調查した。このうち質問紙調查において服楽の記入に 不備があった 7 名を除外し，747名（男性317名,女性 430 名, 平均年齢 54.39 歳 S. D. $=10.87$ )を検討対象とした。 歯肉増殖の判定は歯肉の肥大が単に炎症性の腫脹でない ものをすべて含めた。また，我々がニフェジピンによる 歯肉增殖の判定に有用とした 4 項目，すなわち，回凸を 伴う, 多発性, 境界が明瞭, 増殖が局所要因だけでは説 明できない，を充足するものを特徴的歯肉増殖と判定し た。別に，質問紙により服薬状況について調查した。な お，予備的に行った調查から，服薬者は自己が受けてい る投薬薬物の呼称を記銘している者がまれであることが 判明したので，以下の方法により服薬状況を判別するこ ととした。歯肉増殖を引き起こすニフェジピンに代表さ れる $\mathrm{Ca}^{2+}$ 拮抗剤は高血圧症治療の第 1 選択薬とみなさ れて処方されていること ${ }^{7,8)}$, 心筋梗塞, 狭心症の治療薬

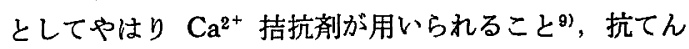

かん薬のフェニトインむ菌肉増殖を引き起こすこと㫜か ら，以下の質問項目により菌肉増殖を引き起こす薬物を 服用している可能性のある集団を選別した。まず，血圧 が高い，普通，低い，を選択させ，次いで血圧の薬，心 臓の薬，けいれん止めの薬をそれぞれ飲んでいるか，飲 んでいないか，過去飲んでいたが現在领んでいないかに ついて質問し，この回答から被検集団を以下に 分類し た。血圧の薬を服用し，かつ血圧が低いとしなかった者 を高血圧治療薬の服用者, 心臟の薬を飲んでいるとした 者を心疾患治療薬服用者, けいれん止めの薬を飲んでい るとした者を抗てんかん薬服用者とみなした。この 3 群 を歯肉増殖性薬物を 現在服用している可能性のある 群 （以下，現在服薬群）とし，更にこれらの薬を過去にの み服用した過去服薬群, 並びにこれらの薬を過去にも現 在にも服用していない非服薬群の 3 群に分け, 各群間の 平均值の差の $\mathrm{t}$ 検定, 群間発現頻度の $\chi^{2}$ 検定または Fisher の直接確率計算で統計学的に比較検討した。ま た, $\mathrm{Ca}^{2+}$ 拮抗剤服薬の可能性のある高血圧, 心疾患の 服薬者の特徴的歯肉增殖の有病率を見るため, 抗てんか ん薬を服用している群を除外した集団についても検討を 行った。

\section{結果}

被検対象を性別に, 年齢, 被検㐘数, 歯肉增殖並びに 特徽的歯肉増殖の出現頻度について比較し Table 1 に 示した。被検歯数は男 22.44 (S. D. =7.74), 女20.22 （S. D. =7.54） で危険率 $5 \%$ で有意差であったが，その 他の項目については性差を認めなかったことから, 以後 男女を合して検討を加えた。その結果, 対象者の平均年 齢は54.39歳 (29-89歳), 被検歯数は平均21.16歯 (2-32 歯）であった。歯肉増殖が認められた者は全体の 12.05 $\%$, 特徵的歯肉増殖の出現頻度は 747 名中の13例で1.74 \%であった。

現在服薬群, 過去服薬群, 非服薬群の 3 群に分けた各 調查項目の成績は Table 2 に示した。歯肉堌殖の有病 率はそれぞれ $15.53 \%, 17.39 \%, 10.42 \%$ あり, 非服薬 群がやや低かったがその差は統計学的有意でなかった。

我々が先にニフェジピンに特徴的と報告した 4 項目を 満足させる特徴的歯肉增殖は, 現在服薬群の12例 $(5.83$ $\%)$, 過去服薬群の 0 例 ( $0 \%)$, 非服薬群の 1 例 $(0.19 \%)$ であった。統計学的に比較すると, 現在服楽群は非服薬 群に較べて高度に有意に多かった（p<0.001）。3群の 年齢比較では, 現在服薬群が非服薬群に較へてて約 9 歳高 く統計学的に有意差であった（p<0.01）。これを，服薬 
Table 1 Oral conditions of the subjects (Male and Female)

\begin{tabular}{ll|c|c|c|c}
\hline \multicolumn{2}{c|}{ Group } & \multicolumn{1}{c|}{$\begin{array}{c}\text { Age } \\
\text { Mean (S.D.) }\end{array}$} & $\begin{array}{c}\text { Examined teeth } \\
\text { per person } \\
\text { Mean (S.D.) }\end{array}$ & $\begin{array}{c}\text { Gingival } \\
\text { hyperplasia } \\
\mathrm{N}(\%)\end{array}$ & $\begin{array}{c}\text { Characteristic } \\
\text { gingival } \\
\text { hyperplasia } \\
\mathrm{N}(\%)\end{array}$ \\
\hline Male & $\mathrm{N}=317$ & $55.02(11.50)$ & $22.44(7.74)-1$ & $43(13.56)$ & $8(2.52)$ \\
Female & $\mathrm{N}=430$ & $53.93(10.37)$ & $20.22(7.54)-$ & $47(10.93)$ & $5(1.16)$ \\
Total & $\mathrm{N}=747$ & $54.39(10.87)$ & $21.16(7.70)$ & $90(12.05)$ & $13(1.74)$ \\
\hline
\end{tabular}

$*: \mathrm{p}<0.05, * *: \mathrm{p}<0.01, * * *: \mathrm{p}<0.001$

Table 2 Oral conditions in the nonmedicated group and in the group receiving anti-hypertension, anti-cardiopathy, or anti-epilepsy drugs

\begin{tabular}{|c|c|c|c|c|}
\hline Group & $\begin{array}{c}\text { Age } \\
\text { Mean (S.D.) }\end{array}$ & $\begin{array}{c}\text { Examined teeth } \\
\text { per person } \\
\text { Mean (S.D.) }\end{array}$ & $\begin{array}{c}\text { Gingival } \\
\text { hyperplasia } \\
\mathrm{N}(\%)\end{array}$ & $\begin{array}{c}\text { Characteristic } \\
\text { gingival } \\
\text { hyperplasia } \\
\mathrm{N}(\%) \\
\end{array}$ \\
\hline Medicated $N=206$ & $60.55(8.66)=$ & $19.36(8.02)$ & $32(15.53)$ & $12(5.83)-$ \\
\hline $\begin{array}{l}\text { Medicated } \\
\text { in past }\end{array}$ & $56.61(7.40)$ _- $\left.\right|_{-1} ^{*}$ & $20.74(7.74) * * *$ & $4(17.39)$ & $0(0)$ \\
\hline $\begin{array}{l}\text { Nonmedicated } \\
\text { (Control) } \quad \mathrm{N}=518\end{array}$ & $51.84(10.80) \stackrel{* * *}{=}$ & $21.89(7.46)-$ & $54(10.42)$ & $1(0.19)$ \\
\hline
\end{tabular}

$*: \mathrm{p}<0.05, * *: \mathrm{p}<0.01, * * *: \mathrm{p}<0.001$

Table 3 Oral conditions in the nonmedicated group and in the group receiving anti-hypertension or anti-cardiopathy drugs

\begin{tabular}{|c|c|c|c|c|c|}
\hline Group & & $\begin{array}{c}\text { Age } \\
\text { Mean (S.D.) } \\
\end{array}$ & $\begin{array}{c}\text { Examined teeth } \\
\text { per person } \\
\text { Mean (S.D.) }\end{array}$ & $\begin{array}{c}\text { Gingival } \\
\text { hyperplasia } \\
\mathrm{N}(\%) \\
\end{array}$ & $\begin{array}{c}\text { Characteristic } \\
\text { gingival } \\
\text { hyperplasia } \\
\mathrm{N}(\%) \\
\end{array}$ \\
\hline Medicated & $\mathrm{N}=203$ & $60.52(8.71) \longrightarrow$ & $19.44(8.03)-$ & $31(15.27)$ & $12(5.91)-$ \\
\hline Medicated in past & $\mathrm{N}=21$ & $56.67(7.65)-1 * *$ & $20.90(7.46) * *$ & $3(14.29)$ & $0(0) \quad * * *$ \\
\hline Nonmedicated (Control) & $N=518$ & $51.84(10.80)=$ & $21.89(7.46)$ & $54(10.42)$ & $1(0.19)-$ \\
\hline
\end{tabular}

$*: \mathrm{p}<0.05, * *: \mathrm{p}<0.01, * * *: \mathrm{p}<0.001$

群中の特徵的歯肉增殖の 12 名で見ると平均年齢 62.08 (S. D. $=6.11)$, 一方, 服薬群中特徵的崡肉増殖のない

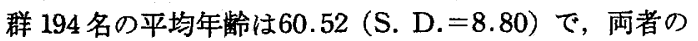
間には統計学的有意差を認めなかった。一人当り被検歯 数む服薬群が非服薬群より約 1 歯少なく, この差は統計 学的に有意であった $(\mathrm{p}<0.01)$ 。

また，抗てんかん薬の服用者とみなした群を除外し， ニフェジピン服用の可能性のある高血圧と心疾患の治療 薬の服薬集団に限定して，改めて集計比較したものが Table 3である。ニフェジピン歯肉増殖症患者にみられ
万特徵的な歯肉増殖は, 高血圧・心疾患治療薬の現在服 薬群203名中の 12 例, 5.91\%に観察され，非服薬群に㧍い ては 1 例の0.19\%のみに認められ，両群間には統計学的 に高度の有意差で現在服薬群に多かった $(p<0.001)$ 。

\section{考察}

慢性辺縁性歯周炎は, 歯周組織の炎症と, 破壊を主症 状とするが，その症状の一つに歯肉增殖も挙げられる。 慢性辺縁性歯周炎の有病状況調查の報告の中に歯肉增殖 に着目してその出現頻度を報告した者は見あたらない。 
本調査の対象者の $12.05 \%$ に歯肉増殖が認められたが, 慢 性辺縁性歯周炎の症状としての歯肉増殖が高い頿度でな いことを示している。

また, 澁肉増殖は服薬状況による群別比較で現在服薬 群では $15.53 \%$, 過去服薬群では $17.39 \%$ であるのに対し， 非服薬群では $10.42 \%$ とやや低いことから，服薬が歯肉 増殖を増加させていることを疑わせるが，群間の有病率 に統計学的な有意差はなかった。

ニフェジピン歯肉增殖症患者にみられる特徴的な歯肉 増殖所見が高血圧・心疾患治療薬の現在服薬群の $5.91 \%$ に観察され，一方，これらの薬の非服薬群においてはわ ずか 1 例の $0.19 \%$ みに認められ，その出現頻度は統計 学的に高度の有意差 $(\mathrm{p}<0.001)$ で現在服薬群に多かっ た。この結果は, 我々の特徴的歯肉増殖の判定法が相当 の妥当性を有していることを示している。しかし特徽的 歯肉増殖がこの薬物の服用経験のない集団からも僅かで あるが見いだされた事実は，非薬物性の歯肉増殖で我々 が判定したニフェジピン歯肉增殖と類似の臨床所見を持 つ歯肉增殖が，まれとはいえ存在することを考慮する必 要があることを示している。

本報告に打ける高血圧 - 心疾患治療薬の現在服薬群の 特徵的歯肉增殖有病率である5.91\%は，先に我々が報告 した ${ }^{2,3)}$ 一民間病院ニフェジピン服薬外来患者の 特徽的 歯肉增殖の有病率である10.9\%のおよそ半分であった。 本来ならば本報告のニフェジピン服薬者の実数が調べら れるのが望まれる。しかし，予備的研究で服薬者本人に 記入させる質問票にニフェジピンの一般名，商品名を予 め記載したものから該当する薬品を選択させる形式にし ても回答が得られることがまれな上，直接本人から聴取 してもなお，服楽薬品名を挙げられないのが実際であっ たので，本報告の上うに高血圧・心疾患治療薬の服薬の 有無を群別基準にせざるを得なかった。もとより，高血 圧・心疾患治療薬の中には降圧利尿剤, 強心剂など $\mathrm{Ca}^{2+}$ 拮抗剤とは異なる 薬理作用を持つ薬物を服用する 者が当然含まれている。そこで，我々が先に一民間病院 で行った高血圧・心疾患患者 93 名中の50名 (53.8\%) が ニフェジピンを現在服薬していた事実(2) を参考に，本 研究対象の高血圧・心疾患治療薬の現在服用群のお㧍よ

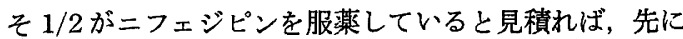
報告した一民間病院のニフェジピン服用者の有病率 10.9 \%のおおよそ $1 / 2$ である本報告の $5.91 \%$ は合理的な数值 といえよう。

なお，服薬群間の年龄比較で高血圧，心疾患による服 薬集団はその疾病の性質上高齡者に多いため, 非服薬集
団よりも平均年龄が高く，また被検歯数も少なかったも のであろうが，歯肉増殖および特徽的歯肉増殖の有病率 が服薬群で高い一要因として年齢の関与む考虑しなけれ ばならない。そこで, 服薬群中の特徵的齿肉增殖群12名 の平均年齢 62.08 を, 服薬群中特徽的歯肉增殖のない群 194 名の 平均年齢 60.52 と比較したところ, 両群間に統計 学的有意差を認めず，特徵的歯肉增殖が増龄によって発 現する傾向があるとはいえないと判断された。

今回, 高血圧 - 心疾患治療薬の現在服用群の $5.91 \%$ に 特徵的な歯肉増殖が発現したことの社会的意義は大きい と言わざるを得ない。現に当予防歯科外来で報告者が扱 ったニフェジピンに由来する特徽的歯肉增殖症患者の 77.7\%は投薬主治医からの紹介無しで発見されたもので あった。症例説明，あるいは歯肉增殖治療上の必要か ら，転薬を依頼するため投薬主治医と懇談することがあ る。その際，歯肉增殖に気付かなかったかを問い合わせ ると，日常診療で咽頭，喉頭を診査するために口腔を診 る習慣はあるが，歯肉を視認することは一般化していな いとの返答が大部分であった。このことは投薬副作用と しての歯肉堌殖の発症の指摘を投薬主治医に期待するこ とが実際的でないことを示している。本剤投薬に当っ て，歯科医師による監視が不可欠と思われる。

なお，薬事法で薬剤には添付文書が義務づけられてい るが, ニフェジピンの歯肉増殖に関しては「連用により まれに歯肉肥厚があらわれることがあるので，このよう な症状があらわれた場合には，投与を中止すること。」101 の記述があるのみである。ここで云う「まれに」は厚生 省薬務局通知 ${ }^{11}$ で副作用発現頻度で $0.1 \%$ 未满とされて おり本報告と, 我々が先に報告したニフェジピン服用者 の特徽的歯肉増殖発現率 $10.9 \%(1987,1990)^{2,3)}$ からも 著しくかけ離れている。ニフェジピンによる歯肉增殖の 有病率についてはその後木下ら（1990） 12)が30.6\%を，

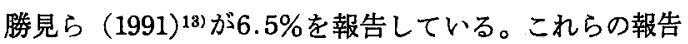
をもとに, 副作用発現頻度が $5 \%$ 以上または頻度不明の 場合は副詞なしとされている厚生省薬務局通知の記載要 領に従えば，「連用により歯肉肥厚があらわれることがあ る」と改められねばならない。また「本剤の投与に当っ ては歯科医師による歯周の監視が必要である」の一項も つけ加えられねばならない。

\section{結論}

宮城県の一農村地区における成人健診受診者 747 名に ついて，歯肉增殖並びにニフェジピン服用者に特徽的な 歯肉増殖の有病状況を増殖性薬物の服用の可能性のある 
群 (現在服薬群), 過去服薬群, 非服薬群に群別して比較 した。

1. 歯肉増殖は被検者の $12.05 \%$ に認められた。

2. 特徽的齿肉増殖の出現頻度は被検者の $1.74 \%$ に認 められた。

3. 現在服薬群, 過去服薬群, 非服薬群の 3 群に杍け る画肉增殖有病者率はそれぞれ $15.53 \%, 17.39 \%, 10.42$ \%で，その差は統計学的に有意でなかった。

4. 特徽的歯肉増殖者は服薬群の $5.83 \%$, 過去服薬群 の $0 \%$, 非服薬群の0.19\%で, 現在服薬群が高度の統計 学的有意差で非服薬群より多かった。

5. 被検対象から抗てんかん薬服用者を除外し，ニフ エジピン服用の可能性のある高血圧，心疾患の治療薬現 在服薬群として集計すると, 特徴的歯肉増殖はその5.91 \%にみられ，過去服薬群の $0 \%$, 非服薬群の $0.19 \%$ との 比較で, 現在服薬群が非服薬群より統計学的高度に有意 に多かった。

\section{謝辞}

稿を終わるに望みこの調查に協力戴いた町の関倸者の 皆様に心からの御礼を申し上げます。

また本研究を支えて戴いた予防歯科学教室の各位に愿 く感謝の意を表します。

\section{文献}

1）渋谷芳郎, 岩倉政城, 島田義弘, 鈴木正規, 刍 井達哉：冠血管拡張剤 Nifedipine の副作用と 思われる料肉增殖症の 1 例, 東北大学歯学誌, $6 ; 51-60,1987$.

2) 岩倉政城, 渋谷芳郎, 小原陽子, 島田義弘: = フェジピン（血圧降下剂）療法を受けている患 者の歯肉增殖有病状況について, 口腔衛生会誌,
$37 ; 574-575,1987$.

3）岩倉政城, 㗪谷芳郎, 安野陽子, 島田義弘: = フェジピン療法を受けている患者の歯肉增殖有 病状況についての予備的研究, 口腔衛生会誌, $40 ; 53-59,1990$.

4）岩合政城, 涉谷芳郎, 島田義弘：血圧降下郕二 フェジピンに由来する歯肉增殖症の臨床所見に ついての検討, 口腔衛生会誌， $38 ； 608-609$, 1988.

5）岩倉政城, 沾谷芳郎, 安野陽子, 島田義弘: 力 ラー写真によるニフェジピン歯肉増殖症の判定 にっいて，口腔衛生会誌， $39 ; 504-505 ， 1989$.

6) 今川与曹, 石川 純 : 臨床歯周病学, 医歯薬出 版, 東京, 1974, 52-88.

7) 增立善明：高血圧症, 日野原重明,阿部正和編: 今日の治療指針, 30巻, 医学書院, 東京, 1988, 344-347.

8) 1989 Guidelines for the management of mild hypertension: Memorandum from a WHO/ ISH Meeting, J. Hypertension, 7 ; 689-693, 1989.

9）中村元臣, 平 則夫編：カルシウム拮抗薬一基 礎と臨床一, 医薬ジャーナル社, 大阪, 全面改 訂版, 1986, 207-303.

10）アダラート・アダラート 5 添付文書, バィェ ル薬品株式会社, 1989年 8 月.

11）厚生省薬務局：医療用医薬品添付文書の記載要 領について, 厚生省薬務局通知薬発第 385 号, 昭 和58年 5 月 18 日付.

12）木下尚樹，国賀就一郎，下邨真哉，國富照子, 清水明彦, 前田密昭, 吉岡 済: カルシウム拮 抗剤服用者の歯肉增殖に関する調查 (抄録), 日 歯周誌, $32 ; 140,1990$.

13）勝美行雄，高原正明，渡辺泰秀，武藤寿孝，熱 田藤雄, 土屋晴仁, 花沢康雄, 高橋喜久雄, 内 山 聡, 金沢春幸, 佐藤研一：降圧剤 (Ca 拮 抗薬）服用による歯肉增殖症の發生率に関する 臨床統計学的観察, 口科誌, $40 ; 169-178,1991$. 